\title{
Upland erosion in a mixed pine forest ecosystem
}

\author{
K D SHARMA* and J F CORREIA** \\ ICAR Research Complex for NEH Region, Shillong 793003, India \\ *Present address: Central Arid Zone Research Institute, Jodhpur 342003, India \\ ** Present address: College of Technology and Agricultural Engineering, Udaipur 313001 , India
}

MS received 17 June 1988; revised 21 October 1988

\begin{abstract}
Starting from basic erosion principles an upland soil erosion model to predict soil loss in humid subtropical monsoon climate by saturation overland flow from individual storms on forested hillslopes can be derived in the form $Q_{s}=n x^{2} k_{f} S^{2 \alpha} Q$, where $Q$, is the total soil loss for a storm event, $n$ the roughness coefficient, $x$ the downslope distance, $k_{f}$ the soil erodability factor, $S$ the slope, $\alpha$ the slope exponent and $Q$ the runoff. An mixed pine forest ecosystem has $n=0.58$ and $\alpha=2 \cdot 1$.
\end{abstract}

Keywords. Flow erosion; effective shear stress; effective rainfall; saturation overland flow.

\section{Introduction}

Soil erosion in upland areas is primarily the result of erosive and transport agents, viz rainfall and overland flow. Rainsplàsh erosion, which detaches and transports soil particles from the soil surface by raindrop impact, and flow erosion, which results from concentrated overland flow, are referred to jointly as upland erosion in the present study. It is understood that upland erosion is an overland flow-dominated process (Chisci 1981; Sharma 1985). It is, however, one of the most elusive processes to observe and measure on land under forest cover (Chorley 1980), and thus, little is known about hillslope erosion processes (Edwards 1977; Kirkby 1980). We have studied upland erosion in a mixed pine forest ecosystem under humid subtropical monsoon climate near Shillong $\left(25.7^{\circ} \mathrm{N}, 91.9^{\circ} \mathrm{E}\right)$, India, during $1983-85$, and the results are reported here.

\section{The study basin}

The study basin (figure 1) forms a part of the Shillong plateau, which is characterized by rolling topography and steep hillslopes. It has an area of 1.9 ha with elevations ranging between 1008 and $1079 \mathrm{~m}$. The rocks are mainly comprised of fractured and faulted quartzites and phyllites. The soils are $>150 \mathrm{~cm}$ deep, yellowish red, have very thick B horizon and are of clay loam type (typic paleudult). Since 1980 the study basin has been maintained under an undisturbed 'good' (Ree et al 1977) mixed pine (Pinus kesiya) forest, Eupatorium adenophorum being the dominant ground species. The mean vegetation density and cover are $13.6 \mathrm{~m}^{-2}$ and $14.2 \mathrm{~cm}^{2} \mathrm{~m}^{-2}$ respectively.

The study area has a humid subtropical monsoon climate with the maximum temperature seldom exceeding $26^{\circ} \mathrm{C}$ and mean annual rainfall of $2079 \mathrm{~mm}$ (30-year- 


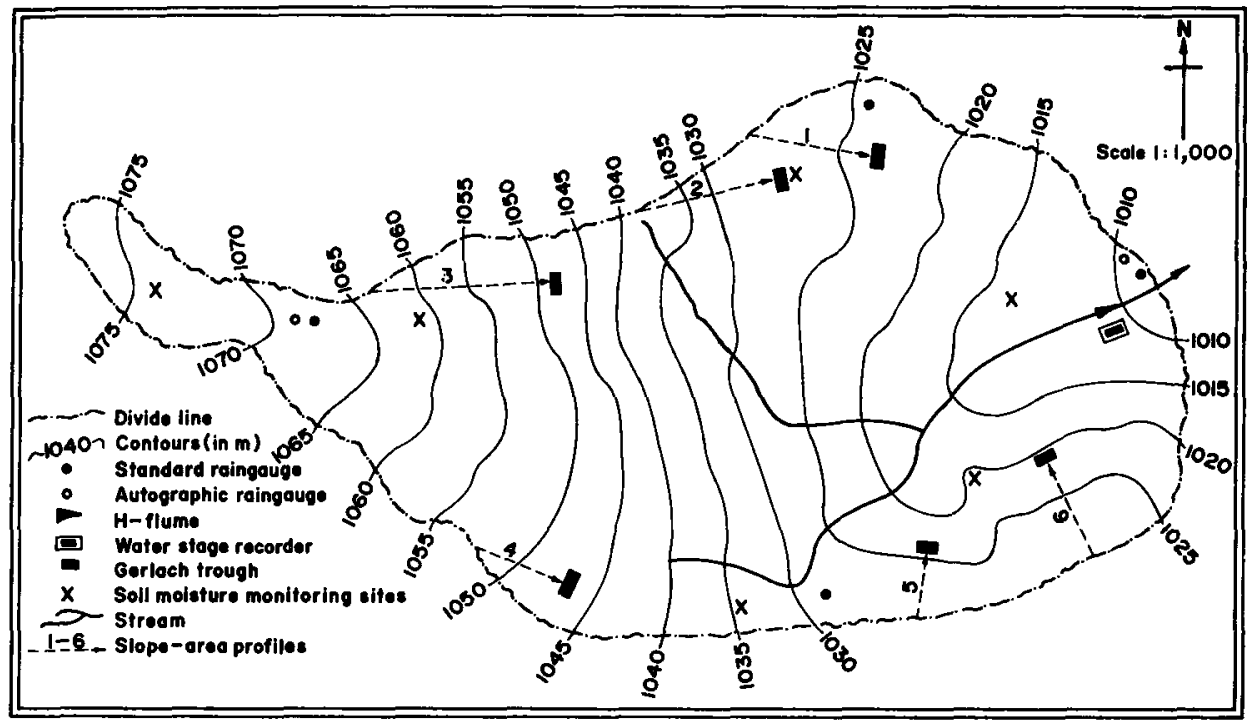

Figure 1. The study basin and gauging network.

average), about $70 \%$ of which occurs during the southwest monsoon period from June to September. The daily rainfall totals with a 10-year return period ranged from 150 to $225 \mathrm{~mm}$. The total annual evaporation was $1577 \mathrm{~mm} \mathrm{yr}^{-1}$, nearly $500 \mathrm{~mm}$ less than the annual rainfall.

\section{Materials and methods}

\subsection{Experimental procedure}

The study involved measurements at a number of sites within the basin so that information about the spatial distribution, controls and local effects of the erosion processes could be obtained. The soil erosion was measured on six slope area land profiles involving non-uniform slope characteristics in the field (figure 2). The main criterion for selection of such profiles was that each profile should cover the entire slope length from the highest point in the basin, i.e. divide, to the mid-slope line which lies halfway between the main stream and the divide (Morgan 1979). Thus, each profile acts as a complete natural basin and conforms to the objective of maintaining natural conditions with respect to the concentration of overland flow and process of erosion due to the runoff (Jinze 1981). Since the runoff was collected at the downstream and of each profile, the overall slope characteristics, such as weighted slope (Sharma and Correia 1987) and total slope length from divide to the mid-slope line, were considered for analysis. The characteristics of the experimental slope area land profiles are given in table 1.

Runoff and soil loss by overland flow were recorded on a storm-by-storm basis from July 1983. Collection was carried out using 0.5-m-wide sediment traps (Gerlach 1967), two traps being placed side by side at each site. Because of the influence of microtopographical variations on soil erosion the two traps were not treated as 


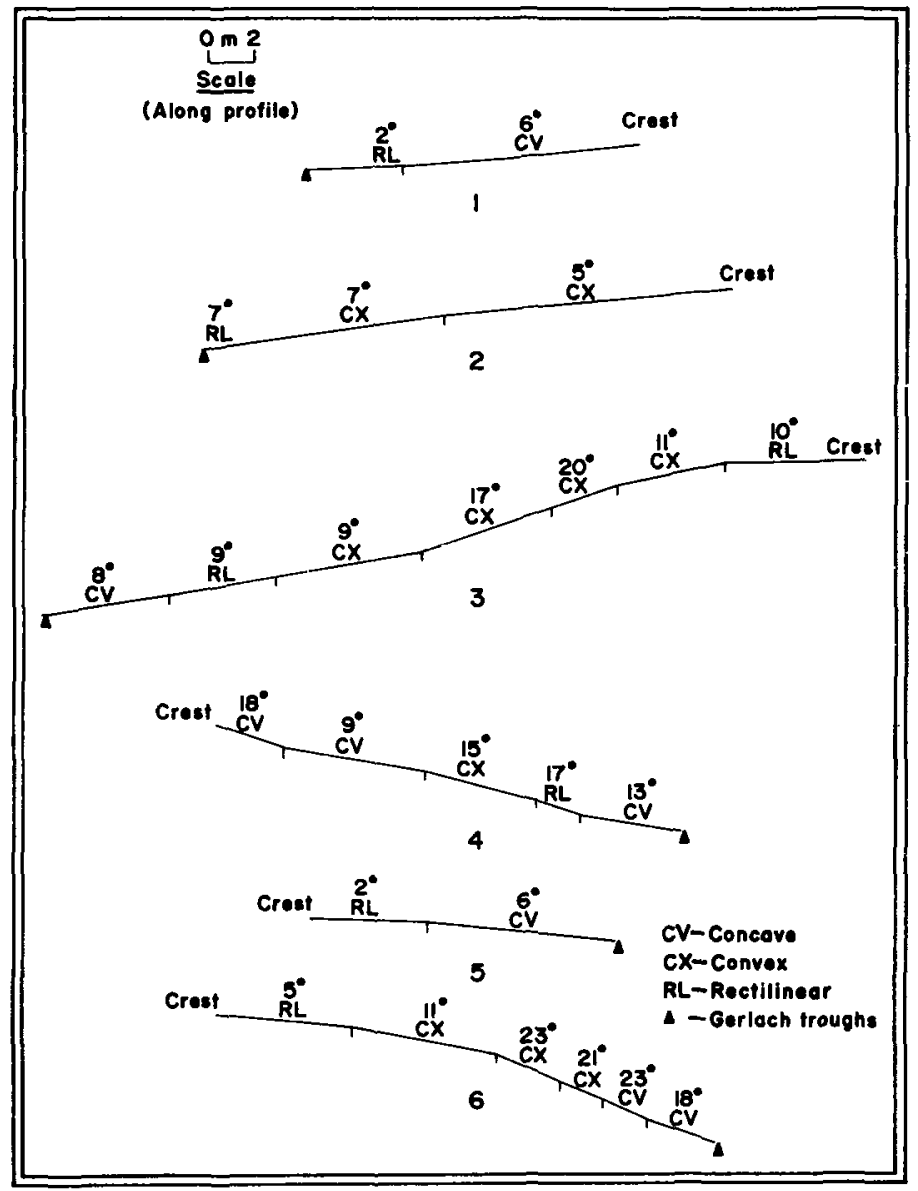

Figure 2. Experimental slope area land profiles.

Table 1. Characteristics of experimental slope area land profiles.

\begin{tabular}{lc}
\hline $\begin{array}{l}\text { Weighted } \\
\text { ground slope } \\
\text { (degrees) }\end{array}$ & $\begin{array}{c}\text { Overall } \\
\text { slope length } \\
(\mathbf{m})\end{array}$ \\
\hline 4.3 & $15 \cdot 7$ \\
5.9 & $22 \cdot 0$ \\
10.0 & $40 \cdot 7$ \\
13.5 & $20 \cdot 3$ \\
4.5 & $12 \cdot 3$ \\
13.8 & $16 \cdot 7$ \\
\hline
\end{tabular}

replicates. Instead, data from the two traps were combined to give an overall value for that site. These traps were arranged en echelon across the slope to ensure a clear run to each set from the divide (figure 3). The traps were visited after each runoff-causing event and the volume of water collected were measured. After thoroughly stirring the sediment-laden water, samples were taken to the laboratory and the sediment 


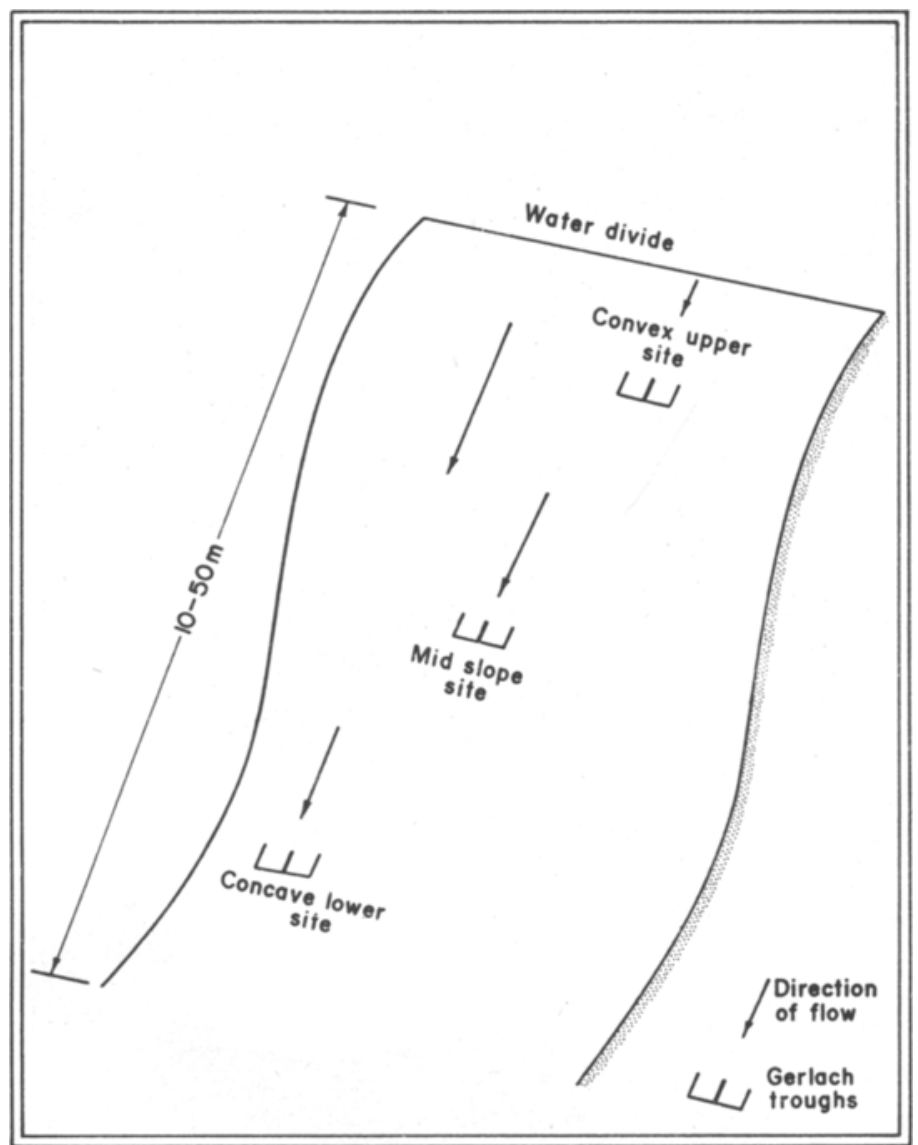

Figure 3. Principle of siting Gerlach troughs on slope profile.

concentrations were determined by standard concentration technique. To determine the sediment yield in each event, the sediment concentration was multiplied by the total volume of runoff, and the product was divided by the width of the trap. Weekly soil moisture storage up to a depth of $15 \mathrm{~cm}$ was monitored gravimetrically from six places, selected randomly within the basin (figure 1). The daily incident rainfall depth and intensity were measured with an autographic rain-gauge installed within the basin.

Between 11 July 1983 and 25 September 1985 erosion occurred on all sites on 87 occasions. This study is concerned with these data.

\subsection{Formulation of upland erosion model}

The basic governing equation of upland erosion processes is the equation of continuity for sediment transport by overland flow (Bennett 1974). In the following analysis negligible dispersion within the flow and a quasi-steady flow are assumed, which simplifies the continuity equation to

$$
\frac{\partial q_{s}}{\partial x}=D_{r}+D_{f}
$$


where $q_{s}$ is sediment load (mass per unit width per unit time), $x$ the downslope distance, $D_{r}$ the rainsplash erosion rate and $D_{f}$ the flow erosion rate, both $D_{r}$ and $D_{f}$ expressed in mass per unit area per unit time. Since in forested ecosystems the contribution of rainsplash erosion is insignificant (Pathak et al 1984; Sharma 1985), (1) reduces to

$$
\frac{\partial q_{s}}{\partial x}=D_{f}
$$

An equation for sediment load is obtained by integrating (2) with respect to distance;

$$
q_{s}=\int D_{f} \cdot \mathrm{d} x .
$$

In most modelling applications erosion and flow are assumed to be uniformly distributed across the slope, although physically the flow and erosion are concentrated in small channels. With this assumption the equation assumed for the flow erosion is (Meyer et al 1975)

$$
D_{f}=a_{s}\left(\tau_{\mathrm{e}}-\tau_{\mathrm{cr}}\right)^{\xi}
$$

where $a_{s}$ is a factor related to the susceptibility of the soil to erosion, $\tau_{\mathrm{e}}$ the effective shear stress, $\tau_{\mathrm{cr}}$ the critical shear stress and $\xi$ an exponent. In many modelling approaches the value of $\tau_{\mathrm{cr}}$ is neglected as it is fictitious and negligible (Foster 1982). Hence (4) reduces to

$$
D_{f}=a_{s} \tau_{\mathrm{e}}^{\xi}
$$

Foster (1982) gave the value of $\xi$ as $3 / 2$ for overland flow erosion. Hence, the expression

$$
D_{f}=a_{s} \tau_{e}^{3 / 2}
$$

is used to indicate the flow erosion rate.

Assuming the effective shear stress to be proportional to average overland flow depth and slope and taking overland flow depth $y$ from the Darcy-Weisbach uniform flow equation, the effective shear stress $\tau_{e}$ is given by

$$
\tau_{\mathrm{e}}=C_{\tau} \gamma(f / 8 g)^{1 / 3} S^{2 / 3} q^{2 / 3}
$$

where $C_{\tau}=\tau_{\mathrm{e}} / \tau_{\mathrm{a}}, \tau_{\mathrm{a}}$ being the actual shear stress and equal to $\gamma y S, \gamma$ the weight density of water, $S$ the slope, $f$ the coefficient of friction, $g$ the acceleration due to gravity and $q$ the discharge per unit width. For steady state $q=\sigma x$, where $\sigma$ is the effective rainfall (rainfall rate minus abstraction rate), and (6) becomes

$$
\tau_{\mathrm{e}}=C_{\tau} \gamma(f / 8 g)^{1 / 3} S^{2 / 3}(\sigma x)^{2 / 3} .
$$

Combining (5) and (7),

$$
D_{f}=a_{s} C_{\mathrm{r}}^{3 / 2} \gamma^{3 / 2}(f / 8 g)^{1 / 2} S \sigma x \text {. }
$$

The product $a_{s} \gamma^{3 / 2}(f / 8 g)^{1 / 2}$ can be lumped into a soil factor $2 k_{f}$, and $C_{\tau}^{3 / 2}$, which is a function of resistance to flow and probably of the slope, can be combined with $S$ as $n S^{\alpha}$ 
where $n$ and $\alpha$ are soil roughness and vegetation retardance factor and slope characteristics factor respectively. Thus, (8) reduces to

$$
D_{f}=2 k_{f}\left(n S^{\alpha}\right) \sigma x .
$$

Substituting the value of $D_{f}$ from (9) into (3) and integrating,

$$
q_{s}=k_{f}\left(n S^{\alpha}\right) \sigma x^{2}
$$

Assuming only $\sigma$ as time-dependent, (10) can further be integrated with respect to time to estimate the soil loss from a storm event. Thus,

$$
Q_{s}=x^{2} k_{f}\left(n S^{\alpha}\right) \int_{0}^{t} \sigma \mathrm{d} t
$$

where $Q_{s}$ is the total soil loss for a storm event (mas per unit per event) and $t$ the time when runoff ends. Hence

$$
Q_{s}=x^{2} k_{f}\left(n S^{\alpha}\right) Q
$$

where $Q=\int_{0}^{t} \sigma \mathrm{d} t=$ volume of runoff (volume per unit area).

\section{Results and discussion}

\subsection{Rainfall and soil moisture storage}

The annual rainfall received in the study basin during 1983-85 varied between 2134 and $2525 \mathrm{~mm}$ as against the 30 -year mean of $2079 \mathrm{~mm}$. Frequency distributions of magnitude and intensity of rainfall events were determined using the data for individually measured storms (tables 2 and 3 ). $73.1 \%$ of the number of storms were of small magnitude, i.e. $<20 \mathrm{~mm}$ and only $2.9 \%$ were $>60 \mathrm{~mm}$. The small magnitude events contributed $33.4 \%$ of the annual rainfall; $15.4 \%$ was contributed by the large magnitude events. The rainfall intensity was $<20 \mathrm{~mm} \mathrm{~h}^{-1}$ for $56.4 \%$ of the storms, contributing one third of the annual rainfall. On the other hand only $2.3 \%$ of the storms were $>100 \mathrm{~mm} \mathrm{~h}^{-1}$ and contributed $7 \cdot 1 \%$ of the annual rainfall. Thus a majority of the storms were of small magnitude, frequent, of prolonged duration (mean storm duration $\simeq 1.5 \mathrm{~h}$ ) and of low intensity. Lowery et al (1982) reported that such storms created temporarily high soil moisture levels and transient perched water tables. This was confirmed with the soil moisture storage data. During the rainy season of June to September the soil moisture storage in the top $15 \mathrm{~cm}$ of soil ranged between 36 and $42 \%$, i.e. at/near saturation.

\subsection{Overland flow}

Widespread overland flow due to rain falling on already saturated soil was observed at all sites and was similar in character to that observed in the field elsewhere (Emmett 1980). Occurrence of widespread saturation overland flow due to perched water table and saturated topsoil was also observed by Bonell and Gilmour (1978), Bonell et al (1984) and Sharma (1985). The overland flow consisted of myriad numerous and 
Table 2. Frequency distribution of rainfall depth.

\begin{tabular}{lcc}
\hline Shower size class & $\begin{array}{c}\text { Frequency, rainfall } \\
(\%)\end{array}$ & $\begin{array}{c}\text { Frequency, events } \\
(\%)\end{array}$ \\
\hline$<20$ & $33 \cdot 4$ & $73 \cdot 1$ \\
$20-40$ & $30 \cdot 2$ & $17 \cdot 3$ \\
$41-60$ & $21 \cdot 0$ & $6 \cdot 7$ \\
$61-80$ & $7 \cdot 8$ & $1 \cdot 8$ \\
$81-100$ & $3 \cdot 8$ & $0 \cdot 7$ \\
$>100$ & $3 \cdot 8$ & $0-4$ \\
Total rainfall (mm) & $2378 \cdot 1$ & $151 \cdot 0$ \\
and number of measured & & \\
events & & \\
\end{tabular}

Table 3. Frequency distribution of rainfall intensity.

\begin{tabular}{lcc}
\hline $\begin{array}{l}\text { Intensity class } \\
\left(\mathrm{mm} \mathrm{h}^{-1}\right)\end{array}$ & $\begin{array}{c}\text { Frequency rainfall } \\
(\%)\end{array}$ & $\begin{array}{c}\text { Frequency, events } \\
(\%)\end{array}$ \\
\hline$<20$ & $33 \cdot 3$ & $56 \cdot 4$ \\
$20-40$ & $24 \cdot 7$ & $20 \cdot 5$ \\
$41-60$ & $19 \cdot 3$ & $11 \cdot 3$ \\
$61-80$ & $9 \cdot 8$ & $6 \cdot 3$ \\
$81-100$ & $5 \cdot 8$ & $2 \cdot 2$ \\
$>100$ & $7 \cdot 1$ & $2 \cdot 3$ \\
Total rainfall (mm) & $1840 \cdot 4$ & $115 \cdot 0$ \\
and number of timed & & \\
events & & \\
\hline
\end{tabular}

separate interlinking and constantly changing flow paths as soil deposits, topographic irregularities and vegetation directed most of the runoff into a lateral concentrations of flow. These gave the appearance of wide, shallow, braided channels. The saturation overland flow across the sites averaged only $0.52 \%$ of the incident rainfall (table 4), indicating that it was a subsurface flow system. Pathak et al (1984) recorded $0.41 \%$ of incident rainfall as overland flow under mixed pine forest in the Kumaun Himalaya. Similarly, Heeds (1984) recorded a ratio between saturation overland flow and precipitation of up to $0.5 \%$ in the south-western Ponderosa pine forests in the USA. Several investigators have also reported that the hydrologic response to rain by a forested hillslope is dominated by the lateral downslope movements of water within the soil layers(Hornback 1973; Chorely 1980; Pathak et al 1984) and that overland flow is a rare occurrence in forested basins (Kirkby 1969; Freeze 1972).

\subsection{Sediment concentrations}

The sediment concentrations observed in runoff samples illustrate the ability of overland flow to erode and transport sediments. Analytical results of several sediment samples from each profile are summarized as averages and given in table 4 . The mean sediment concentrations for all the sites varied between 6.98 and $14.36 \mathrm{gl}^{-1}$, giving an average of $9 \cdot 55 \mathrm{~g} \mathrm{l}^{-1}$. Sediment concentration shows a negative correlation with rainfall amount $(r=-0 \cdot 20, n=87)$ and a positive correlation with rainfall intensity $(r=0 \cdot 20$, 
Table 4. Average values of overland flow, sediment concentration and sediment yield compared to ground slope characteristics from the experimental slope area land profiles.

\begin{tabular}{|c|c|c|c|c|c|c|}
\hline \multirow{3}{*}{$\begin{array}{l}\text { Weighted } \\
\text { ground slope } \\
\left(\mathrm{m} \mathrm{m}^{-1}\right)\end{array}$} & \multirow{3}{*}{$\begin{array}{c}\text { Slope } \\
\text { length } \\
(\mathrm{m})\end{array}$} & \multicolumn{2}{|c|}{ Overland flow } & \multirow{3}{*}{$\begin{array}{c}\text { Sediment } \\
\text { concentration } \\
\left(\mathrm{gl}^{-1}\right)\end{array}$} & \multirow{2}{*}{\multicolumn{2}{|c|}{ Sediment yield }} \\
\hline & & & & & & \\
\hline & & $(\mathrm{mm})$ & rainfall) & & $\left(\mathrm{kgha}^{-1}\right)$ & $\left(g^{-1}\right)$ \\
\hline 0.0752 & $15 \cdot 7$ & 0.057 & 0.49 & 6.98 & $2 \cdot 94$ & $4 \cdot 61$ \\
\hline 0.1033 & $22 \cdot 0$ & $0-051$ & 0.44 & $9 \cdot 57$ & $3 \cdot 14$ & 6.90 \\
\hline $0 \cdot 1763$ & $40 \cdot 7$ & $0-033$ & 0.28 & $8 \cdot 11$ & $2 \cdot 25$ & $9 \cdot 14$ \\
\hline $0 \cdot 2401$ & $20 \cdot 3$ & $0 \cdot 057$ & 0.49 & 10.21 & $5 \cdot 46$ & $11 \cdot 09$ \\
\hline 0.0787 & $12 \cdot 3$ & $0 \cdot 103$ & 0.88 & $8 \cdot 09$ & $6 \cdot 17$ & $7 \cdot 59$ \\
\hline 0.2456 & $16 \cdot 7$ & 0.063 & 0.55 & $14 \cdot 36$ & $8 \cdot 27$ & $13 \cdot 81$ \\
\hline
\end{tabular}

$n=87$ ). These relationships were, however, statistically insignificant. The lack of a significant correlation was observed over a wide range of rainstorm intensities and durations including an extreme rainstorm with peak intensity of $192 \mathrm{~mm} \mathrm{~h}^{-1}$ on 21.8.84. An unsystematic trend clearly indicates that rainfall depth and intensity were not the dominant factors in soil erosion processes in the forested ecosystem studied.

No significant correlation ( $r=-0 \cdot 176, n=87$ ) seems to exist between average sediment concentration and mean runoff yield (figure 4). A possible explanation for this is that even at the highest recorded runoff rates, flow energy is apparently below the critical value needed to overcome the cohesion of the soil and to provide a substantial amount of eroded material. At the same time, the relatively high concentrations recorded at low runoff rates point to the importance of processes responsible for preparing loose soil aggregates liable to be transported by shallow, low-velocity flows. Among these processes, alternate wetting and drying of the soil surface and activity of rodents etc. are important. The observations thus suggest the existence of two types of materials in the drained area; one easily removed by shallow, low-velocity flows and the other highly resistant to erosion even at high-energy flows. Similar results have also been reported by Yair and Lavee (1981) and Sharma et al (1984).

\subsection{Sediment yield}

The sediment yield is a function of sediment production by erosion and subsequent transport of the sediments. Hence the sediment yield is limited either by extent of soil erosion or by sediment transport capacity depending on the basin characteristics and rainfall-runoff relationship. The sediment yield usually varies at different locations within a basin (Mildner et al 1972). In the present study, the average sediment yield varied from 2.25 to $8.27 \mathrm{~kg} \mathrm{ha}^{-1}$ per event with a mean of $4.71 \mathrm{~kg} \mathrm{ha}^{-1}$ per event (table 4). These values are lower than the sediment yields $\left(15.3\right.$ and $32.0 \mathrm{~kg} \mathrm{ha}^{-1}$ per event) reported by Pandey et al (1983) and Pathak et ai (1984) respectively from the central Himalaya for land under similar forest cover.

The sediment yield shows a positive trend $(r=0.20, n=87 ; r=0.14, n=87$ respectively) with rainfall depth and intensity, although this is statistically insignificant. Sediment yield also shows positive correlation with overland flow depth $(r=0.51$, $n=87$ ) at $1 \%$ level of significance. Kirkby (1971), Gabriels et al (1972), Morgan (1980), 


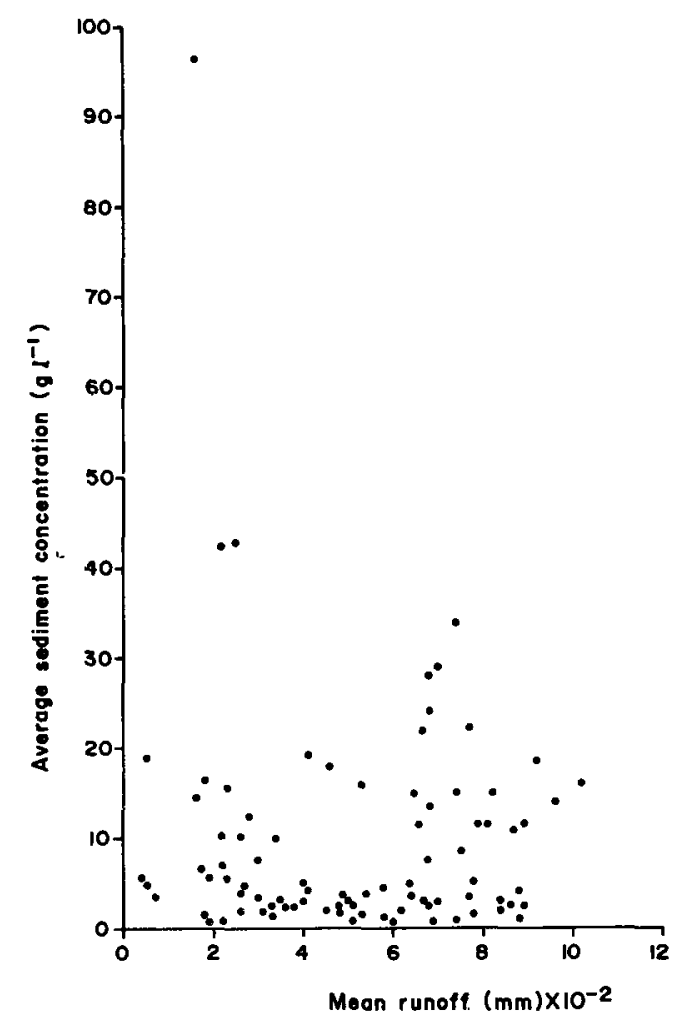

Figure 4. Relationship between average sediment concentration and mean runoff.

Pandey et al (1983) and Pathak et al (1984) also reported a positive relationship between soil loss and overland flow. Sediment yield, when plotted against runoff (figure 5), shows a general increase of the former with the latter according to the relation

$$
S_{y}=1032 Q^{1 \cdot 92}, \quad\left(R^{2}=0 \cdot 82, n=87\right)
$$

where $S_{y}$ is mean sediment yield ( $\mathrm{kg} \mathrm{ha}^{-1}$ per event) and $Q$ the mean overland flow (mm per event). This is because higher runoff is associated with greater kinetic energy of flow for erosion and transport of the eroded sediments. The above results indicate that the soil erosion from forested hillsides is an overland-flow-dominated process and the contribution of rainfall in eroding the soil through rainsplash is not significant. This can be attributed to the moderation of the impact of the falling raindrop through dispersion and abstraction of rainfall by the vegetation, the rainfall reaching the ground thus becoming nonerosive. Similar results have also been reported by Lull (1964) and Sharma (1985).

The relationship between sediment yield and slope characteristics was found to be

$$
S_{y}=2837 \tan \theta L^{-1 \cdot 6}, \quad\left(R^{2}=0 \cdot 95, n=6\right),
$$

where $S_{y}$ is mean sediment yield ( $\mathrm{kg} \mathrm{ha}^{-1}$ per event), $\theta$ the slope angle (degree) and $L$ the slope length $(\mathrm{m})$. The negative exponent of the slope length may be attributed to the reduction, beyond some critical value, of the average runoff velocity over the 


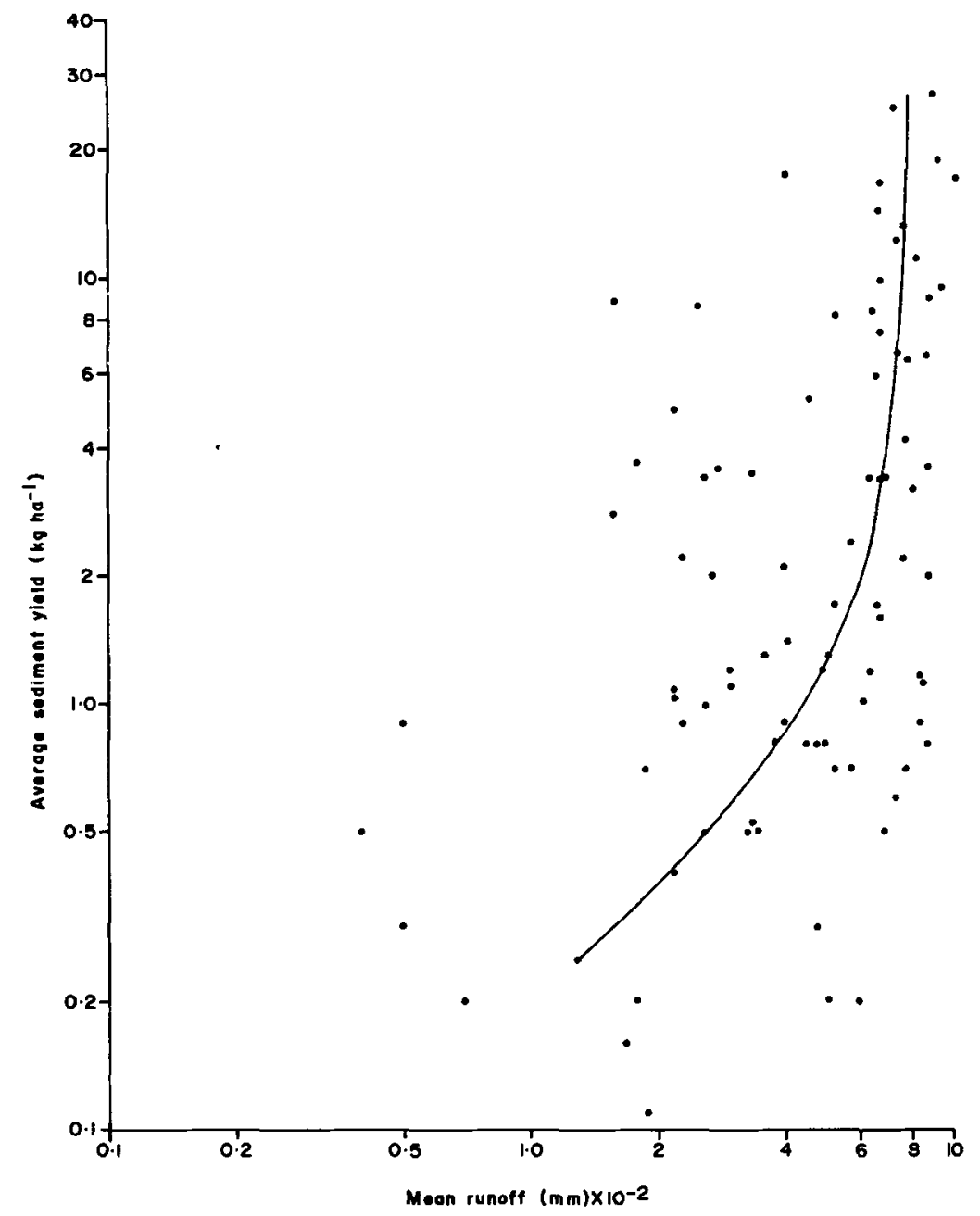

Figure 5. Relationship between average sediment yield and mean runoff.

hillside with increasing travel length since the vegetation acts as a barrier against the flow and results in the deposition of part of the coarser material on the way before the flow reaches the trough. Lal (1981) has also reported lower sediment yields per unit area from long slopes. However, this observation needs further confirmation in the field.

\subsection{Upland erosion model fitting and its validation}

The upland erosion model (equation 12) has been calibrated with a sample of 46 erosive events recorded during the years 1983 and 1984 and validated with 41 erosive events recorded during the year 1985. By the least squares technique (Snedecor and Cochran 1968) values of the roughness coefficient $n$ and slope exponent $\alpha$ were determined which yielded the final upland soil erosion equation

$$
Q_{s}=0 \cdot 58 x^{2} k_{f} S^{2 \cdot 1} Q
$$


The value of $k_{f}$ was taken as $42 \cdot 12 \mathrm{~g} \mathrm{~m}^{-2} \mathrm{~mm}^{-1}$ as reported by Awasthi (1984) under similar conditions in this region. Here $Q_{s}$ is the total soil loss ( $\mathrm{g} \mathrm{m}^{-1}$ per event), $x$ the slope length $(\mathrm{m}), k_{f}$ the soil erodability factor $\left(\mathrm{g} \mathrm{m}^{-2} \mathrm{~mm}^{-1}\right), S$ the slope of land surface for the length $x\left(\mathrm{~m} \mathrm{~m}^{-1}\right)$ and $Q$ the depth of overland flow (mm).

The value of roughness coefficient $n$ as derived in the present model $(0 \cdot 58)$ lies within the ranges 0.21 to 0.62 and 0.52 to 0.66 reported by Emmett (1980) from overland flow surfaces of a grassed watershed and laboratory channel experiments with a similar grass covers respectively. Also, the value of the slope exponent $\alpha$, found to be $2 \cdot 1$ in the present case, is in agreement with that of Kirkby (1969), who found a range of the slope exponent of 1.3 to 2.0 for soil erosion by overland flow.

If the predicted values using (15) are compared with the observed values for soil loss, a correlation coefficient of $r=0.93$ is obtained, which is significant at $1 \%$ level of probability (figure 6). With a coefficient of determination of $86 \%$, the model can be used for predictive purposes. The observed and predicted soil losses were related by the regression equation

$$
Y=0 \cdot 42+0.86 X, \quad\left(\mathrm{SE}_{\mathrm{est}}=2 \cdot 38 \mathrm{~g} \mathrm{~m}^{-1}\right)
$$

where $Y$ is observed soil loss $\left(\mathrm{g} \mathrm{m}^{-1}\right)$ and $X$ is predicted soil loss $\left(\mathrm{g} \mathrm{m}^{-1}\right)$. The chi-square (Snedecor and Cochran 1968) value of 113.58 lies within the range between probability levels of 0.50 and 0.25 , which indicates that the model fitting was good.

\section{Conclusion}

Small-magnitude $(<20 \mathrm{~mm})$, frequent, prolonged and low-intensity $\left(<20 \mathrm{~mm} \mathrm{~h}^{-1}\right)$ storms create temporarily high soil moisture levels and transient perched water tables in upland basins. The resulting overland flow is a saturation overland flow and accounts for only $0.52 \%$ of the incident rainfall in a mixed pine forest ecosystem. Soil erosion in these ecosystems is an overland flow dominated process.

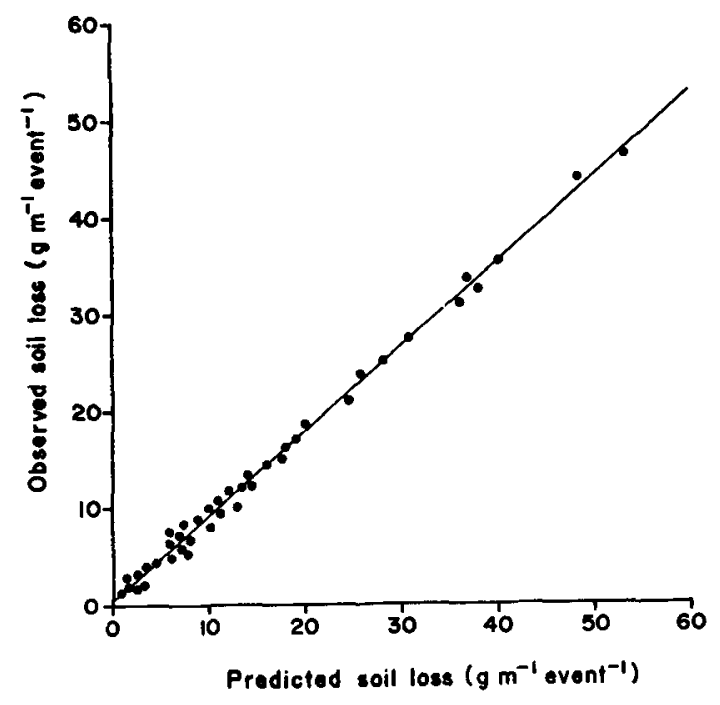

Figure 6. Comparison of observed and predicted soil loss. 


\section{References}

Awasthi R P 1984 Studies on the production potential, runoff, soil and nutrient losses under different systems of cropping and management practices on steep slopy jhum land $\mathrm{Ph} . \mathrm{D}$. dissertation, Bidhan Chandra Krishi Viswavidyalaya p. 139

Bemmett J P 1974 Concepts of mathematical modelling of sediment yield; Water Resour. Res. 10 485-492

Bomell M, Hendriks M R, Imeson A C and Hazelhoff L 1984 The generation of stream runoff in a forested clayey drainage basin in Luxembourg; $J$. Hydrol. 71 53-77

Bomell $M$ and Gilmour D A 1978 The development of overland flow in a tropical rainforest catchment; J. Hydrol. 39 365-382

Chisci G 1981 Upland erosion evaluation and measurement; in Symposium on Erosion and sediment Transport Measurement (Oxford: IAHS Pub. No. 133) pp. 331-349

Chorely R J 1980 The hillslope hydrological cycle; in Hillslope Hydrology (ed.) M J Kirkky (New York: John Wiley) pp. 1-42

Edwards K A 1977 Cultural practices and changes in catchment hydrology - a review of hydrological research techniques as aid to development planning in the humid tropics; in Soil Conservation and Management in the Humid Tropics (eds) D J Greenland and R Lal (New York: John Wiley) pp. 33-46

Emmett W W 1980 Overland flow; in Hillslope Hydrology (ed.) M J Kirkky (New York: John Wiley) pp. $145-176$

Foster G R 1982 Modelling the erosion process; in Hydrologic Modelling of Small Watersheds (eds) C T Haan, H P Johnson and D L Brakensiek (Michigan: ASAE) pp. 297-380

Freeze R A 1972 Role of sub-surface flow in generating surface runoff e. up-stream source areas; 'Water Resour. Res. 8 1272-1283

Gabriels D, Pauwels J M and De Boodt M 1972 A quantitative rill erosion study on a loamy sand in the hilly region of Flanders; Earth Surface Processes 2 257-259

Gerlach T 1967 Hillslope troughs for measuring the overland flow and sediment movement: Rev. Geomorphol. Dyn. 17 170-172

Heeds B H 1984 Overland flow and sediment delivery; J. Hydrol. 72 261-273

Hornbeck J W 1973 Storm flow from hardwood forested and cleared watersheds in New Hampshire: Water Resour. Res. 9 346-354

Jinze M 1981 The establishment of experimental plots for studying runoff and soil loss in the rolling less regions of China; in Symposium on Erosion and sediment Transport Measurement (Oxford: IAHS Pub No. 133) pp. $467-477$

Kirkby M J 1969 Erosion by water on hilislopes; in Water, Earth and Man (ed.) R J Chorley (London: Methuen) pp. 215-277

Kirkby M J 1971 Erosion by water on hillslopes; in Introduction to Fluvial Processes (ed.) R J Chorley (London: Methuen) pp. 98-107

Kirkby M J 1980 Implications for sediment transport; in Hillslope Hydrology (ed.) M J Kirkby (New York: John Wiley) pp. 325-362

Lal R 1981 Analysis of different processes governing soil erosion by water in the tropics; in Symposium on Erosion and Sediment Transport Measurement (Oxford: IAHS Pub. No. 133) pp. 351-364

Lowery B, Kling G F and Vomcil J A 1982 Overland flow from sloping land-effects of perched water tables and sub-surface drains; Soil Sci. Soc. Am J. 46 93-99

Lull W H 1964 Ecological and silvicultural aspects; in Handbook of Applied Hydrology (ed.) V T Chow (New York: McGraw Hill) pp. 6·1-6·30

Meyer L D, Foster G R and Nikalov S 1975 Effect of flow rate and canopy on rill erosion; Trans. ASAE 18 905-911

Mildner W F, Bali J S and Nanda H S 1972 Handbook of Sedimentation (New Delhi: Ministry of Agriculture) pp. $6 \cdot 1-6 \cdot 21$

Morgan R P C 1979 Soil Erosion (London: Longman) pp. 15-41

Morgan R P C 1980 Field studies of sediment transport by overland flow; Earth Surface Processes $5307-316$

Pandey A N, Pathak P C and Singh J S 1983 Water, sediment and nutrient movement in forested and nonforested catchments in Kumaun Himalaya; For. Ecol. Management 7 19-29

Pathak P C, Pandey A N and Singh J S 1984 Overland flow, sediment output and nutrient loss from certain forested sites in the central Himalaya, India; J. Hydrol. 71 239-251

Ree W O, Wimberley F L and Crow F R 1977 Manning and the overland flow equation; Trans. $A S A E$ $2089-93$ 
Sharma K D 1985 Upland erosion in a humid steep hill catchment M. Eng. dissertation, Sukhadia University, $125 \mathrm{p}$.

Sharma K D and Correia J F 1987 Use of weigated slope instead of mean slope with soil loss relationship in the humid steep hill basin; J. Indian Soc. Soil Sci. 35 171-173

Sharma K D, Vangani N S and Choudhary J S 1984 Sediment transport characteristics of the desert streams in India; J. Hydrol. 67 261-272

Svedecor G W and Cochran W G 1968 Statistical Methods (New Delhi: Oxford and IBH) 593 p.

Yair A and Lavee H 1981 An investigation of source areas of sediment and sediment transport by overland flow along arid hill slopes; in Symposium on Erosion and Sediment transport Measurement (Oxford: IAHS Pub. No. 113) pp. 433-446 